\title{
PENGARUH POLA ASUH ORANG TUA DAN DIET BEBAS GLUTEN/KASEIN TERHADAP PERBAIKAN GEJALA AUTISM SPECTRUM DISORDER (ASD)
}

\author{
Sari Eka Pratiwi \\ Fakultas Kedokteran Universitas Tanjungpura Pontianak, Indonesia \\ Email: sariekapratiwi@medical.untan.ac.id
}

Fitri Sukmawati

Fakultas Ushuludin Adab dan Dakwah Insitut Agama Islam Negeri Pontianak, Indonesia

Email: ghandur78@gmail.com

Diterima Tanggal: 20 November 2018

Selesai Tanggal 26 Mei 2019

\section{ABSTRACT}

Autism Spectrum Disorder (ASD) is a development impairment characterized by cognitive and neurobehavioral deficit, including communication and social problem that need psycology and education intervention for the children and the parents, also nutrition intervention with Gluten-Free Casein-Free (GFCF). This study's aim is to identify the parenting style and Gluten-Free Casein-Free diet role in ASD's symptoms modification. This study was start with collecting the references and research publications, and study the relationship of parenting style and GFCF diet to ASD. Flexible Parenting style in ASD is important and need to be adjusted based on the characteristic, development stage and the children's situation. Diet GFCF can be a complementary therapy to reduce ASD's symptoms particularly children with gluten allergy and have celiac disease. However, the children without any gastrointestinal symptoms to gluten/casein products need a consideration and advance examination to determine GFCF diet requirement.

[Autism Spectrum Disorder (ASD) merupakan suatu kelainan perkembangan saraf yang dicirikan dengan adanya defisit kognitif dan neurobehavioralyang mencakup masalah komunikasi dan perilaku sosial, yang memerlukanintervensi psikologis dan edukasi pada anak dan orang tua, serta intervensi nutrisi dengan pembatasan asupan gluten dan kasein yang dikenal dengan diet Gluten-Free Casein-Free (GFCF). Penulisan telaah jurnal ini bertujuan untuk mengetahui pengaruh pola asuh orang tua dan pembatasan asupan gluten dan kasein terhadap perbaikan gejala ASD. Penulisan telaah literatur dilakukan dengan mengumpulkan berbagai sumber teori dan hasil penelitian kemudian dilakukan telaah terhadap hubungan kedua faktor yaitu pola asuh dan pembatasan asupan gluten dan kasein terhadap ASD. Gaya pengasuhan pada ASD perlu dilakukan secara fleksibel sesuai dengan keunikan karakter anak, tahap perkembangan anak, dan situasi yang sedang dihadapi. Terapi pembatasan asupan gluten/kasein dapat menjadi pilihan terapi pelengkap untuk mengurangi gejala ASD terutama pada anak yang alergi gluten dan mengalami penyakit celiac. Namun, pada anak yang tidak memiliki gejala saluran cerna terhadap produk gluten/kasein perlu pertimbangan dan pemeriksaan lebih lanjut untuk menentukan perlu tidaknya pembatasan gluten/kasein pada makanannya].

Kata Kunci: Autism Spectrum Disorder (ASD), Gluten-Free Casein-Free (GFCF), Pola Asuh Pada ASD, Autisme, Terapi Nutrisi Autism Spectrum Disorder (ASD). 



\section{PENDAHULUAN}

Autism Spectrum Disorder (ASD) merupakan suatu kelainan perkembangan saraf yang dicirikan dengan adanya defisit kognitif dan neurobehavioral,dengan faktor utama adalah genetik, dan terjadi hingga 1 dari 68 anak usia sekolah di Amerika Serikat, dengan perbandingan laki-laki dan perempuan 5:1. ASD sendiri mencakup masalah komunikasi dan perilaku sosial yang membutuhkan pendidikan, perilaku dan pelayanan kesehatan yang intensif ${ }^{1}$.

Berdasarkan Diagnostic and Statistical Manual of Mental Disorder (DSM) edisi ke 4, autism dicirikan dengan adanya gangguan pada interaksi sosial, komunikasi, dan pola perilaku, ketertarikan dan aktivitas yang restriktif, repetitif dan stereotipik. Edisi ke-5 DSM menyatukan diagnosis autistic disorder dan sindrom Asperger menjadi Autism Spectrum Disorder (ASD). Pada anak dengan ASD ini, seringkali mengalami gangguan saluran cerna. Anak dengan ASD memiliki gangguan pada komunikasi sehingga sulit

\footnotetext{
${ }^{1}$ Buie, T. 'The Relationship of Autism and Gluten', CLITHE. Elsevier Inc., 2013: 35(5), pp. 578-583; Zuckerman, K. E. et al. (2014) 'Family Impacts Among Children With Autism Spectrum Disorder: The Role of Health Care Quality', Academic Pediatrics. Elsevier Ltd, 14(4), pp. 398407; Onaolapo, A. Y. and Onaolapo, O. J. (2017) 'Global Data on Autism Spectrum Disorders Prevalence: A Review of Facts, Fallacies and Limitations', 5(2), pp. 14-23; Putri, A. et al. (2017) 'Penyebab gangguan autis melalui jalur neuroinflamasi', 3(2), pp. 1-9.
}

menjelaskan nyeri yang dirasakannya, dan hal ini dapat bermanifestasi sebagai masalah perilaku sebagai akibat dari adanya suatu penyakit yang dideritanya ${ }^{2}$.

Berbagai strategi pengobatan alternatif dan pelengkap dilakukan untuk memperbaiki kualitas hidup anak dengan ASD. Berbagai cara termasuk intervensi psikologis dan edukasi, serta intervensi nutrisi dengan pembatasan asupan gluten dan kasein yang dikenal dengan diet Gluten-Free Casein-Free (GFCF). Dalam intervensi diet ini semua makanan yang mengandung gluten seperti gandum, dan kasein yang dapat ditemukan dalam produk susu harus dihilangkan dari menu harian anak ASD. Sebagian besar orang tua dengan anak ASD meyakini bahwa anak ASD memiliki alergi terhadap komponen gluten dan kasein, walaupun tidak dilakukan uji untuk mengkonfirmasi hal ini. Terdapat beberapa keuntungan jenis diet ini yang dilaporkan oleh orang tua,

${ }^{2}$ Buie, T. 'The Relationship of Autism and..., pp. 578-583; Baxter, A. J. et al. (2015) 'The Epidemiology and Global Burden of Autism Spectrum Disorders', Psychological Medicine (2013), (45), pp. 601-613; Putri, A. et al. (2017) 'Penyebab gangguan autis melalui jalur neuroinflamasi', 3(2), pp. 1-9; Khalil, A. I. and Elarousy, W. (2018) 'Health Care Providers ' Knowledge about Using Gluten and Casein Free Diet (GFCF) for Improving Behavioral Disorders of Autistic Children : A Dietary Health Care Providers ' Knowledge aboutUsing Gluten andCasein Free Diet ( GFCF ) for Improving Behaviora', IOSR Journal of Nursing and Health Science (IOSRJNHS), 7(4), pp. 64-75. 
yaitu perubahan pada bicara dan perilaku ${ }^{3}$. Telaah literatur ini bertujuan untuk mengetahui peran pola asuh orang tua termasuk pembatasan asupan gluten dan kasein pada perbaikan gejala ASD, sehingga diharapkan terapi pelengkap ini dapat memperbaiki tumbuh kembang anak ASD.

\section{METODE}

Telaah literatur dimulai dengan penelusuran sumber-sumber teori dan hasil penelitian mengenai peran pola asuh orang tua dan pembatasan asupan gluten dan kasein terhadap perbaikan gejala ASD pada anak-anak. Kemudian dilakukan analisis dengan menghubungkan berbagai hasil penelitian untuk mendapatkan kesimpulan yang tepat.

\section{PEMBAHASAN}

\section{Pola Asuh Orang Tua mempengaruhi perkembangan ASD}

Membesarkan anak dengan ASD sangat berhubungan dengan tingginya stress psikologi pada orang tua, dan beberapa penelitian menunjukkan adanya peran penting kesehatan psikologis orang

3 Khalil AI, Elarousy W. Health Care Providers ' Knowledge about Using Gluten and Casein Free Diet (GFCF) for Improving Behavioral Disorders of Autistic Children: A Dietary Health Care Providers ' Knowledge aboutUsing Gluten andCasein Free Diet (GFCF) for Improving Behaviora. IOSR J Nurs Heal Sci. 2018;7(4):64-75. tua terhadap masalah perilaku anak. Semakin rendah penerimaan psikologis orang tua, semakin tinggi masalah kesehatan mental orang tua dan semakin tinggi pula masalah perilaku pada anak ${ }^{4}{ }^{(7)}$

Pola asuh orang tua atau yang sekarang popular dengan Parenting memiliki konotasi lebih aktif daripada parenthood (masa menjadi orang tua). Di Amerika istilah parenting berarti menjalankan serangkaian keputusan tentang sosialisasi kepada anak.(8)Le Vine (dlm Berns, 2004) tujuan parenting yaitu:menjamin kesehatan dan keselamatan fisik, mengembangkan kapasitas perilaku untuk menjaga diri dengan pertimbangan ekonomis, dan pemenuhan kapasitas perilaku untuk memaksimalkan nilai-nilai budaya. ${ }^{(8)}$

Di Indonesia istilah parenting adalah pengasuhan. Menurut Kamus Bahasa Indonesia (2008), pengasuhan berarti hal (cara perbuatan) mengasuh. Mengasuh mengandung makna menjaga/merawat/mendidik, membimbing/membantu/melatih, memimpin/ menyelenggarakan. Makna pengasuhan bertujuan untuk meningkatkan

${ }^{4}$ Weiss JA, Cappadocia MC, Macmullin JA, Viecili M. The impact of child problem behaviors of children with ASD on parent mental health: The mediating role of acceptance and empowerment. Sage Publication. 2012;16(3):26174. 
atau mengembangkan kemampuan anak dan dilakukan dengan dilandasi rasa kasih sayang tanpa pamrih.Pengasuhan anak akan memberikan hasil yang lebih baik apabila ayah dan ibu menjalankan pengasuhan bersama (coparenting) yaitu orang tua saling bekerja sama bukan saling bertentangan dalam merawat dan menjaga perkembangan anak baik fisik dan psikisnya.

Pelaksanaan pengasuhan bersama dipengaruhi oleh faktor status perkawinan, konteks, karakteristik ayah, ibu dan anak. Peran orang tua baik ayah dan ibu yang dijalankan dengan baik, akan memberikan hasil yang lebih baik jika ayah dan ibu saling mendukung, mengingat bahwa anak masih benar-benar tergantung pada perawatan dan pengasuhan oleh ibunya ${ }^{5}$.

\section{Jenis Pola Pengasuhan Anak}

Terdapat berbagai jenis pola pengasuhan anak, diantaranya adalah pola otoriter (keras), permisif (lunak) dan moderat (otoritatif). Otoriter (keras), jenis pengasuhan ini sangat tegas dengan melibatkan bentukl aturan". Anak dibiasakan dengan pemberian hadiah dan hukuman. Masalah yang muncul dengan pengasuhan ini adalah anak akan

${ }^{5}$ Lubis. R.2008. Hubungan Pola Asuh Ibu Dengan Satus Gizi Anak Balita Di Wilayah Kerja Puskesmas Pantai Cermin Kecamatan Tanjug Pura Kabupaten Lagnkat. mengharapkan hadiah atas kelakuan baiknya tersebut. Dan akan sangat menimbulkan ketakutan dan kemarahan yang berlebihan dengan hukuman keras yang diberikan.Permisif (lunak), yaitu orangtua menggunakan cara dengan tidak memberikan batasan dan biasanya anak akan tumbuh tanpa arahan. Masalah yang akan muncul dengan cara ini adalah anak tidak perduli dengan tanggung jawab sosial dan akan mengalami kesulitan dalam bergaul. Moderat (otoritatif), gaya pengasuhan ini didasari atas pengertian dan rasa hormat orangtua terhadap anaknya. Orangtua memberikan aturan yang sesuai dengan usia dan perkembangan anak. Orangtua yang fleksibel dan otoritatif mendorong anak untuk membicarakan masalah yang dihadapinya., memberikan penjelasan yang rasional dan masuk akal tentang peran anak di rumah.

Terdapat dua pendekatan pengasuhan yaitu pendekatan tipologi (gaya pengasuhan) dan pendekatan interaksi social $^{6}$. Pendekatan tipologi ada dua yaitu:

1. Demandingness, yaitu tuntutan orang tua mengenai keinginan menjadikan anak sebagai bagian keluarga, harapan perilaku dewasa disiplin.

${ }^{6}$ Lewis, C.2005. Parenting and the family. In B. Hopkins (Ed) The Cambridge Encyclopedia of Child Development (pp.340-343). Cambridge University Press. 
2. Responssiveness, yaitu ketanggapan orang tua dalam membimbing kepribadian anak, membentukketegasan sikap, pengaturan diri.

Kedua Faktor diatas mewujudkan tindakan penerimaan, suportif, sensitif terhadap kebutuhan dan lainnya. Tipologi ini dipelopori oleh Baumrind (1991) dengan 4 gaya pengasuhan sebagai kombinasi dua faktor tersebut yaitu ${ }^{7}$ :

1. Authoritative (mengarahkan perilaku anak secara rasional dengan memberikan penjelasan terhadap maksud dari aturan yang berlaku).

2. Authoritarian (banyak aturan dan tuntutan, namun kurang penjelasan dan kurang peka terhadap kebutuhan dan pemahaman terhadap anak),

3. Permissive (memberikan kebebasan pada anak dengan menerima dan memaklumi segala perilaku, namun kurang menuntut sikap tanggung jawab),

4. Rejecting -neglecting (pembebasan anak sudah berlebihan dan sama sekali tanpa teguran dari orang tua menandakan bahwa orang tua tidak peduli terhadap anak).

7 Baumrind, D. 1991. The influence of parenting style on adolescent competence and substance use. The journal of Early Adolescence, 11 (1), 56-95. DOI: 10.1177/02724316911111004.
Gaya pengasuhan merupakan serangkaian sikap yang ditunjukkan orang tua untuk menciptakan iklim emosi yang melingkupi interaksi orang tua anak. Gaya pengsuhan otoritatif dianggap sebagai gaya pengasuhan paling efektif menghasilkan akibat positif pada anak. Dalam cakupan lebih luas konteks sosial dan budaya turut mempengaruhi pelaksanaan pengasuhan. Generalisasi pengaruh kesukuan dan keberagamaan terhadap pengasuhan menghasilkan dua kelompok orientasi kolektif dan individualistik.

\section{Hak-hak Anak dalam Pengasuhan}

Adapun hak-hak anak dalam pengasuhan orang tua yaitu : (1). Hak untuk dapat hidup, tumbuh, berkembang dan berpartisipasi secara wajar, (2). Hak atas suatu nama sebagai identitas diri dan status kewarganegaraan., (3). Hak untuk beribadat menurut agamanya, berfikir dan berekspresi, (4). Hak untuk mengetahui orang tuanya, (5). Hak memperoleh pelayanan kesehatan dan jaminan sosial, (6). Hak untuk memperoleh pendidikan dan pengajaran, (7). Hak untuk menyatakan dan didengar pendapatnya, (8). Hak untuk beristirahat dan memanfaatkan waktu luang, (9). Hak untuk mendapatkan perlindungan dari 
diskriminatif, dan(10). Setiap anak berhak diasuh oleh orangtuanya sendiri.

\section{Peran Orang Tua}

Orang tua mempunyai peran dalam membina tumbuh kembang anak yang disebut dengan kebutuhan anak. Kebutuhan anak antara lain: (1) Kebutuhan fisik/jasmani, hal ini membutuhkan untuk pemenuhan gizinya; (2) Kebutuhan emosi, disini orang tua senantiasa memberikan kasih sayang, rasa aman, percaya diri, perasaan diterima orang tua dengan kondisi apa adanya anaknya; (3) Kebutuhan sosial, anak perlu dibiasakan dan dilatih untuk dapat melakukan penyesuaian diri dengan norma lingkungan yang ada; dan, (4) Kebutuhan intelektual, orang tua berkewajiban memberikan stimulus kepada anak dalam memberikan rangsangan sensori, kebebasan berpendapat.

Dalam mendidik anak, orang tua harus mempunyai kesadaran pengasuhan untuk menghindari kondisi anak yang kurang berkembang dengan sehat dan maksimal. Hal ini karena pengasuhan merupakan tanggung jawab utama orang tua.Rasa tanggung jawab muncul karena adanya tuntutan sosial tentang kewajiban memenuhi kebutuhan fisik psikis anak. Harapan dan tanggung jawab pengasuhan akan menciptakan model dalam mengasuh dan membesarkan anak. Kesadaran pengasuhan merupakan sarana mengoptimalkan potensi anak, mengarahkan mencapai kesejahteraan dan membantu menyelesaikan tugas perkembangan dalam kehidupan dengan baik.

\section{Stress Pengasuhan}

Orang tua yang tidak siap untuk mengasuh dengan baik dan maksimal, akan mengalami adanya. Stress pengasuhan. Deater-Deckard (2004) mengatakan bahwa merupakan serangkaian proses yang membawa pada kondisi psikologis yang tidak disukai dan reaksi sosial yang muncul dalam upaya beradaptasi dengan tuntutan peran sebagai orang tua.Stres pengasuhan dapat dipahami sebagai situasi penuh tekanan yang terjadi pada pelaksanaan tugas pengasuhan anak.Stres pengasuhan dapat disebabkan ranah orang tua, ranah anak ranah hubungan orang tua anak.Karakter orang tua tertentu yang memicu seperti mudah depresi, kesehatan buruk, dan lain-lain ${ }^{8}$

Anak juga dapat memicu stres pengasuhan seperti kemampuan anak beradaptasi rendah, suasana hati yang buruk, dan lain-lain.Hubungan orang tua

\footnotetext{
${ }^{8}$ Deater-Deckkard, K. 2004. Intoduction to Family Stress. New Haven: Yale University Press.
} 
anak memicu stres pengasuhan yaitu deraja konflik yang muncul dalam interaksi orang tua anak. Ketiga ranah tersebut akan menyebabkan kemerosotan kualitas dan efektivitas perilaku pengasuhan. Seperti menurunnya ekspresi kehangatan, kurang konsisten perilaku pengasuhan.

\section{Gaya Pengasuhan dan Interaksi Orang tua dan Anak}

Kesadaran pengasuhan yang diikuti oleh kesediaan penerimaan diri terhadap gaya pengasuhan, akan meningkatkan kemampuan mengelola stres pengasuhan.Penelitian Willinger dkk (2005) bahwa kombinasi empati , kedekatan, kehangatan emosi, dan afeksi di satu sisi, serta otonomi dan memperkenankan anak mandiri, berkorelasi dengan rendahnya stres pengasuhan ${ }^{9}$. Atribut orang tua yang mendukung rendahnya tingkat stres adalah memiliki kompetensi yang tinggi sebagai orang tua, integritas sosial baik. Gaya pengasuhan perlu dilakukan secara fleksibel sesuai dengan keunikan karakter anak, tahap perkembangan anak, dan situasi yang sedang dihadapi. Orang tua adalah fasilitator bagi perkembangan anak

${ }^{9}$ Willinger, U., Diendorfer-Radner, G., Willnauer, R., Jorgl, G., \& Hager, V. 2005. Parenting Stress and Parental Bonding. Behavioral Medicine, 31(2), 63-69. DOI: 10.3200/BMED.31.2.63-72. agar menjadi pribadi yang tangguh di masa dewasanya.

\section{Perilaku dan Praktik Pengasuhan}

Praktik pengasuhan adalah perilaku pengasuhan dengan muatan tertentu dan memiliki tujuan sosialisasi ${ }^{10}$. Bentukbentuk perilaku pengasuhan yang terdapat dalam relasi orang tua anak yaitu:

1. Kontrol dan pemantauan

Kontrol merupakan dimensi pengasuhan yang positif, dimana kontrol psikologi adalah upaya-upaya pengendalian yang bersifat memaksa terhadap perkembangan psikologis dan emosi anak, misalnya proses berpikir, pengungkapan diri, ekspresi emosi, dan kelekatan pada orang tua. Kontrol perilaku adalah upaya orang tua untuk mengatur dan mengelola perilaku anak. Cara mengontrol dapat dibedakan menjadi dua yaitu kontrol yang jelas (overt) dan kontrol yang tersamar (covert). Kontrol yang jelas dapat dilakukan melalui pemberian hukuman. Sedangkan kontrol yang tersamar dapat dilakukan melalui pemberian pujian dan hadiah.

10 Darling, N. \& Steinberg, L. 1993. Parenting styleas context an integrative model. Psychological Bulletin, 113(3), 487-496. DOI:10.1037/0033-2909.113.3.487. 
Pemantauan (monitoring)

merupakan salah satu cara orang tua untuk mengembangkan kontrol pada anak. Dengan melakukan pemantauan, orang tua memiliki pengetahuan tentang aktivitas yang dilakukan anak. Pemantauan terhadap aktivitas anak dibagi menjadi dua yaitu metode pasif dan aktif. Pasif dengan mengetahui aktivitas rutin atau mendapatkan informasi dari orang lain yang mengetahui tanpa menanyakannya pada anak. Metode aktif dengan menanyakan langsung pada anak atau berpartisipasi dalam aktivitas yang dilakukan anak.

2. Dukungan dan keterlibatan.

Dukungan orang tua akan mencerminkan respon orang tua atas kebutuhan anak yang sangat penting. Dukungan orang tua sebagai interaksi yang dicirikan dengan: perawatan, kehangatan, persetujuan dan berbagai perasaan positif orang tua kepada anaknya. Dukungan orang tua menjadikan anak merasa nyaman terhadap kehadiran orang tua yang menjadikan anak merasa diterima.

Keterlibatan orang tua merupakan derajat yang ditunjukkan orang tua dalam hal ketertarikan, berpengetahuan dan kesediaan untuk berperan aktif dalam aktivitas anak.
Keterlibatan orang tua juga dapat diartikan sebagai persepsi orang tua terhadap keterlibatan dalam pengasuhan anak dalam bentuk partisifasi aktif ketika bermain dan mengisi waktu luang maupun kontribusi substantive dalam perawatan dan supervise.

3. Komunikasi

Clark dan Shileds menemukan bukti bahwa komunikasi yang baik antara orang tua-anak berkorelasi dengan rendahnya keterlibatan anak dalam perilaku delinkuen. Komunikasi orang tua anak sangat penting bagi orang tua dalam upaya melakukan kontrol, pemantauan, dan dukungan pada anak. Tindakan orang tua untuk mengontrol, memantau dan memberikan dukungan dapat dipersepsikan positif atau negatif oleh anak dipengaruhi cara orang tua berkomunikasi ${ }^{11}$.

4. Kedekatan

Kedekatan merupakan aspek penting dalam kehangatan dalam pengasuhan dan keterlibatan anak dalam aktivitas keluarga. Kedekatan orang tua dengan anak, memberikan keuntungan secara tidak langsung dan tidak langsung,

${ }^{11}$ Clark, R.D \& Shileds, G. 1997. Family Communication and Deliquency. Adolesscence, 32 9125), 81-92. 
tergantung sejauhmana kedekatan itu terbentuk.

5. Pendisiplinan

Pendisiplinan merupakan salah satu bentuk dari upaya orang tua untuk melakukan control pada anak. Pendisiplinan biasanya dilakukan orang tua, agar dapat menguasai suatu komptensi, melakukan pengaturan diri, dapat mentaati peraturan dan mengurangi perilaku yang menyimpang. Cara pendisiplinan orang terhadap anak dibedakan menjadi tiga, yaitu unjuk kekuasaan (power assertion), teknik induktif (induction), dan penarikan kasih saying (love withdrawal).

Pengasuhan anak akan memberikan hasil yang lebih baik apabila ayah dan ibu menjalankan pengasuhan bersama (coparenting) yaitu orang uta saling bekerja sama bukan saling bertentangan.Pelaksanaan pengasuhan bersama dipengaruhi faktor status perkawinan, konteks, karakteristik ayah, ibu dan anak. Peran orang tua baik ayah dan ibu yang dijalankan dengan baik, akan memberikan hasil yang lebih baik jika ayah dan ibu saling mendukung.

\section{PerlukahDiet bebas Gluten/Kasein pada anak ASD?}

Anak-anak dan remaja dengan ASD seringkali mengalami permasalahan pada saluran cerna, proses sensori abnormal, alergi makanan dan gangguan pada oromotor, serta memiliki resiko terjadinya kekurangan gizi. Sebagai contoh yaitu rendahnya asupan kalsium pada pasien ASD akibat pembatasan produk susu pada diet bebas gluten dan kasein (Gluten-free casein-free/ GFCF). Kondisi ini tentu memerlukan perhatian bahwa anak dan remaja dengan kondisi ASD memerlukan perhatian dan intervensi khusus pada nutrisinya ${ }^{12}$.

ASD diyakini disebabkan oleh adanya faktor genetik yang berperan penting dalam perkembangannya ${ }^{13}$. Namun terdapat faktor lain yang juga berperan yaitu autoimunitas familial, permasalahan metabolik, inflamasi, neuroimun dan modifikasi epigenetik akibat pengaruh lingkungan maupun asupan makanan ${ }^{14}$. Hubungan antara autism dan gluten diyakini akibat adanya sensitivitas

${ }^{12}$ Tas AA. Dietary strategies in Autism Spectrum Disorder (ASD). Prog Nutr. 2019;20(4):554-62.

13 Buie T. The Relationship of Autism and..., hlm. 583.; Khalil AI, Elarousy W. Health Care Providers ' Knowledge about ..., hlm. 64-75.

14 Buie T. The Relationship of Autism and..., hlm. 583.; Putri A, Sari P, Amin M, Lukiati $\mathrm{B}$, Biologi P, Malang UN. Penyebab gangguan autis ..., hlm. 1-9. 
terhadap gluten dan sering dikaitkan dengan penyakit celiac. Penyakit celiac merupakan suatu kelainan imun yang dikenal sebagai enteropati sensitif-gluten atau celiac sprue, yang diakibatkan oleh kelainan autoimun yang dipicu oleh asupan produk berbahan dasar gandum sehingga terjadi kerusakan pada usus halus. Namun, penyakit celiac ini berbeda dengan gangguan saluran cerna akibat gluten. Sebagian besar pasien dengan gejala saluran cerna akibat gluten, tidak memiliki penyakit celiac. Gangguan pencernaan terkait asupan gluten, dapat diakibatkan oleh respon alergi, respon terhadap gangguan pencernaan produk gluten, atau perubahan mikroba maupun sistem imun di saluran cerna. Manifestasi klinis alergi makanan pada saluran cerna yaitu nyeri, konstipasi, diare, ruam, dan gangguan tidur $^{15}$.

Terdapat teori yang menyebutkan bahwa terdapat perbaikan klinis ketika sebagian anak dengan autis diberikan terapi berupa pembatasan gluten dan kasein, tanpa adanya gejala celiac atau alergi. Namun, metabolit dari gluten dan kasein ini juga terdeteksi pada anak tanpa gejala klinis penyakit celiac maupun alergi. Sehingga dapat disimpulkan bahwa pembatasan gluten dapat membantu pasien

\footnotetext{
${ }^{15}$ Buie T. The Relationship of Autism and..., hlm. 583.
}

ASD yang disertai dengan penyakit celiac, alergi makanan terhadap produk gluten atau adanya gangguan digesti pada produk makanan yang mengandung gluten. Pembatasan asupan gluten ini tidak memberikan dampak terhadap perbaikan perilaku anak $\mathrm{ASD}^{16}$.

Asupan kasein dan gluten dapat menghasilkan molekul peptide yang berfungsi sebagai opioid eksogen, dan dapat teridentifikasi pada urin pasien skizofrenia dan autis. Peptide ini dapat berikatan dengan reseptor opioid dan diyakini dapat berefek pada sistem saraf dengan mempengaruhi kadar opioid pada otak, yang mengakibatkan terjadinya isolasi sosial seperti yang terjadi akibat efek opioid.Berdasarkan teori KelebihanOpioid, terdapat individu yang memiliki kecenderungan produksi enzim digestif pencerna gluten dan kasein yang tidak adekuat, sehingga hal ini meningkatkan permeabilitas usus. Produksi enzim yang tidak adekuat ini, mengakibatkan peptide dari gluten dan kasein mengalami kebocoran kedalam aliran darah, kemudian bersirkulasi dan dapat menembus system sawar darah otak. Gejala-gejala ASD diyakini merupakan dampak dari penempelan peptide pada reseptornya di sel saraf. Serangkaian peristiwa inilah yang

\footnotetext{
${ }^{16}$ Buie T. The Relationship of Autism and..., hlm. 583 .
} 
menjadi dasar adanya teori yang menyebutkan pembatasan asupan gluten dan kasein untuk mengurangi gejala ASD dan memperbaiki perilaku sosial, kognitif dan bicara ${ }^{17}$.

Berdasarkan teori-teori yang telah dipaparkan, maka dapat disimpulkan bahwa terapi pembatasan asupan gluten/kasein dapat menjadi pilihan terapi pelengkap untuk mengurangi gejala ASD terutama pada anak yang alergi gluten dan mengalami penyakit celiac. Namun, pada anak yang tidak memiliki gejala saluran cerna terhadap produk gluten/kasein perlu pertimbangan dan pemeriksaan lebih lanjut untuk menentukan perlu tidaknya pembatasan gluten/kasein pada makanannya. Hal ini mengingat bahwa terdapat kecenderungan kekurangan kalsium pada anak ASD akibat pembatasan asupan bahan tertentu terutama kasein. Diperlukan penelitian lebih lanjut mengenai efektivitas pemberian diet GFCF ini pada anak ASD.

\section{DAFTAR PUSTAKA}

Buie T. (2013). "The Relationship of Autism and Gluten". CLITHE

\footnotetext{
${ }^{17}$ Buie T. The Relationship of Autism and..., hlm. 583.; Khalil AI, Elarousy W. Health Care Providers' Knowledge about Using ..., hlm. 64-75.; Weiss JA, Cappadocia MC, Macmullin JA, Viecili M. The impact of child problem behaviors ..., hlm. 261-74.
}

[Internet]. 2013; 35(5). Available from:

http://dx.doi.org/10.1016/j.clinthe ra.2013.04.011.

Onaolapo AY, Onaolapo OJ. (2017). "Global Data on Autism Spectrum Disorders Prevalence: A Review of Facts", Fallacies and Limitations, 5(2).

Zuckerman KE, Lindly OJ, Bethell CD, Kuhlthau K. (2014). "Family Impacts Among Children With Autism Spectrum Disorder: The Role of Health Care Quality". Acad Pediatr [Internet], 14(4):398-407. Available from: http://dx.doi.org/10.1016/j.acap.2 014.03.011.

Putri A, Sari P, Amin M, Lukiati B, Biologi P, Malang UN. (2017). "Penyebab Gangguan Autis Melalui Jalur Neuroinflamasi”, $3(2)$.

Baxter AJ, Brugha TS, Erskine HE, Scheurer RW, Vos T, Scott JG. (2015). "The Epidemiology And Global Burden Of Autism Spectrum Disorders", Psychol Med, (45).

Khalil AI, Elarousy W. (2018). "Health Care Providers, Knowledge about Using Gluten and Casein Free Diet ( GFCF ) for Improving Behavioral Disorders of Autistic Children: A Dietary Health Care Providers' Knowledge about Using Gluten and Casein Free Diet (GFCF) for Improving Behaviora, IOSR J Nurs Heal Sci, 7(4).

Weiss JA, Cappadocia MC, Macmullin JA, Viecili M. The impact of child 
problem behaviors of children with ASD on parent mental health: The mediating role of acceptance and empowerment. sagepublication. 2012;16(3):26174.

Bern. (2004). Chil, Family, School, Community: Socializaton nd Support. Sixt Edition. Belmont: wadsworth/Thomson Learning.

Lubis. R. (2008). Hubungan Pola Asuh Ibu Dengan Satus Gizi Anak Balita di Wilayah Kerja Puskesmas Pantai Cermin Kecamatan Tanjug Pura Kabupaten Langkat.

Lewis, C. (2005). "Parenting and the family". In B. Hopkins (Ed) The Cambridge Encyclopedia of Child Development (pp.340-343). Cambridge University Press.

Baumrind, D. (1991). "The influence of parenting style on adolescent competence and substance use". The journal of Early Adolescence, 11

DOI: 10.1177/02724316911111004.

Deater-Deckkard, K. (2004). Intoduction to Family Stress. New Haven: Yale University Press.

Willinger, U., Diendorfer-Radner, G., Willnauer, R., Jorgl, G., \& Hager, V. (2005). "Parenting Stress and Parental Bonding". Behavioral Medicine, 31(2). DOI: 10.3200/BMED.31.2.63-72.

Darling, N. \& Steinberg, L. (1993). "Parenting Styleas Context An Integrative Model". Psychological Bulletin, 113(3).

DOI:10.1037/00332909.113.3.487.
Clark, R.D \& Shileds, G. (1997). "Family Communication and Deliquency". Adolesscence, 32 9125).

Tas AA. (2019). "Dietary strategies in Autism Spectrum Disorder (ASD)". Prog Nutr. 20(4).

Pennesi CM, Klein LC. (2012). "Effectiveness of the gluten-free, casein-free diet for children diagnosed with autism spectrum disorder", Based on parental report, 15(2). 
Sari Eka Pratiwi dan Fitri Sukmawati

Pengaruh Pola Asuh Orang Tua Dan Diet Bebas Gluten/Kasein Terhadap Perbaikan Gejala Autism Spectrum $\operatorname{Disorder}(A S D)$ 